\title{
The Potential of Ustadzah in Improving the Existence of Madrasah Ibtidaiyah Ma'arif Sanggulan Tabanan, Bali
}

\author{
*Suharsono ${ }^{1}$, Jumari $^{2}$ \\ ${ }^{1,2}$ Sekolah Tinggi Agama Islam (STAI) Denpasar, Jl. Angsoka Cargo Permai, Indonesia \\ *staidenpasar@gmail.com
}

\begin{abstract}
One of the factors that play a role in the success of Madrasahs is the potential for female teachers, considering that the teacher profession is very much in demand by women. And the research locus that will be researched by the author, the majority of the teachers are women. Based on this background, the following problems can be raised: 1) The potential of female teachers in improving the existence of MI Ma'arifTabanan Bali for the 2020 academic year? and 2) What are the constraints and solutions for the coaching program for female teachers at MI Ma'arifTabanan? This study uses a qualitative research method, which by definition is a research procedure that produces descriptive data in the form of written words or words from people or observable sources. Sources of data or words in this study were obtained by the author through interviews with people who can be trusted. In this study the authors collected data through several informants including: 1. Head of Madrasah. 2. Management of the Ma'arif Education Institute. 3. Teachers. 4. Employees. 5. Madrasah Committee. Based on the explanation of the results of the research and discussion by the author, it can be concluded that female teachers have the potential to improve the existence of Madrasah IbtidaiyahSanggulanTabanan for the 2020 Academic Year. This is in accordance with the theoretical study which states that potential is an ability that has various possibilities or hopes for further development, either in the form of strength, power, or ability that is obtained by the community directly or through a long process.
\end{abstract}

Faktor yang berperan terhadap keberhasilan Madrasah salah satunya adalah potensi ustadzah (guru perempuan), mengingat profesi guru sangat banyak sekali diminati oleh kaum perempuan. Dan fokus penelitian yang akan diteliti oleh penulis mayoritas gurunya adalah kaum perempuan. Berdasarkan latar belakang tersebut maka dapat diajukan permasalahan, yang pertama potensi ustadzah dalam meningkatkan eksistensi MI Ma'arif Tabanan Bali Tahun Ajaran 2020 serta apa kendala dan solusi program pembinaan terhadap para ustadzah di MI Ma'arif Tabanan. Penelitian ini menggunakan metode penelitian kualitatif, yang secara devinisi merupakan prosedur penelitian yang menghasilkan data deskriptif berupa kata-kata tertulis atau lesan dari orang-orang atau sumber yang dapat diamati. Sumber data atau kata-kata dalam penelitian ini diperoleh penulis melalui wawancara dengan orang-orang yang dapat dipercaya. Dalam penelitian ini penulis mengumpulkan data melalui beberapa informan diantaranya kepala 
madrasah, pengurus lembaga pendidikan ma'arif, para guru, karyawan dan komite madrasah. Berdasarkan pemaparan hasil penelitian dan pembahasan yang penulis lakukan, maka dapat diambil kesimpulan bahwa Guru Perempuan memiliki potensi dalam meningkatkan eksistensi Madrasah Ibtidaiyah Sanggulan Tabanan Tahun Pelajaran 2020. Hal ini sesuai dengan kajian teori yang mengatakan bahwa potensi adalah suatu kemampuan yang mempunyai berbagai kemungkinan atau harapan untuk dikembangkan lebih lanjut, baik itu berupa kekuatan, daya, ataupun kesanggupan yang diperoleh masyarakat secara langsung ataupun melalui proses yang panjang.

Keywords: Potentials, ustadzah, Existence

Received: December 08, 2020; Revised: December 19, 2020; Accepted: December 31, 2020

\section{INTRODUCTION}

In many public discussions in the modern era, it turns out that the struggle for gender equality that has long been echoed, in reality shows that the role of women in the perspective of equal rights and position with men has been advanced and developed. This cannot be separated from the awareness of women themselves about the importance of education for the future of mankind, especially Muslim women, in facing equal work and career competition with men. In the historical context, at least the role of women in education has been carried out by the wife of the Prophet Muhammad saw, such as the role of siti Aisyah ra, who is well known for her intelligence and services in narrating several hadiths. Ibn Syihab al-Zuhri once said, "If the knowledge of all humans, including the knowledge of the wives of the Prophet. in comparison, the knowledge of "Aisyah is the most extensive."

Then during the Fatimid dynasty in Egypt, which represented the political power of gender representation in Islamic politics. This dynasty was recorded as a dynasty that developed Islamic studies of Shia schools in Egypt by establishing Jami 'al-Azhar as the forerunner of Al-Azhar University to become a center for educational and scientific development in its time.

Still related to the discussion of women in the Alquran itself, there are many verses that describe women. Regarding gender equality the writer would like to quote the Alquran surah Attaubah verse 71 which reads:

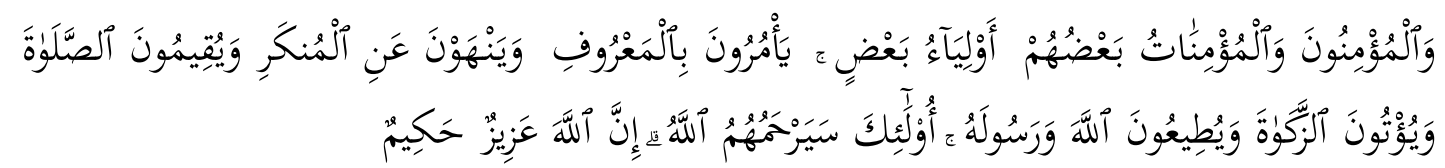

And the believers, men and women, some of them (are) helpers of others. They enjoin what is good, forbid what is evil, establish prayer, pay the poor-due, and obey Allah and His Messenger. They will be given mercy by Allah; surely Allah is Mighty, Wise (Q.S At Taubah no.71) (Departemen Agamag RI, 2020).

If we look at the meaning of the above verse, it can be concluded that there is no difference between men and women in terms of doing and helping in good, and commanding to do good and forsake evil. 
Even women have some advantages over men. There are many terms that only women have. Among them are mentioned the terms of the Capital, Fingers, Mother Earth, Dharma Wanita and even the term or word Angel. All these terms are not possessed by men.

So is the gait of women in the world of education in the current era. Not a few women dominate the world of education. For example, the number of female students is more than the number of males. Similarly, the number of female educators can also be said to be balanced and even more likely than men.

Referring to the notes from the P2KBP3A (Population Control, Family Planning, Women's Empowerment and Child Protection) website of Badung Regency which states that the 21 st century teacher profession is also inseparable from the role of female teachers in building the education of children and female teachers more than male teachers, (Wigati \& Riyadi, 2019).

Similarly, the phenomenon that occurred in the educational institution Madrasah Ibtidaiyah Ma'arif Sanggulan Tabanan. Most of the teachers there are women. Of the total number of teachers as many as 13 people, there are 10 female teachers and 3 male teachers. Based on the existing facts, the author is very interested in conducting more in -depth research to find out to what extent, and how the potential of teachers and what efforts have been made by teachers so that the existence of an educational institution can still survive and tend to grow and develop in the middle. In the midst of stiff competition in the world of education.

According to Law number 20 of 2003 on the National Education System Article 1, regarding the general provisions of item 6 , educators are educational personnel who are qualified as teachers, lecturers, counselors, study assistants, scholars, tutors, instructors, facilitators, and other appropriate designations (Undang-Undang Republik Indonesia, 2003). with its specificity, as well as participate in organizing education. In other words, it can also be said that the role of teachers in education is as follows.

At least nineteen roles of teachers in learning. The nineteen roles of teachers in learning, namely, teachers as educators, teachers, mentors, trainers, advisors, innovators, models and role models, individuals, researchers, creativity boosters, viewers, routine workers, camp shippers, storytellers, actors, emancipators, evaluators, preservatives, and as culminators, (E. Mulyasa: 2004). An educator must have a standard of competence. It is a basic ability that must be possessed by an educator or teacher. The competence that must be owned by the teacher consists of four components. Namely pedagogical competence, personality competence, social competence, and professional competence. Because a teacher is someone who is gugu and imitated in the sense of a person who has charisma or dignity so it is necessary to imitate (follow) and be emulated.

Therefore, the quality of teachers who in their duties always interact directly with students is needed to achieve the goals of education in Indonesia in general and the goals of schools in particular.In the book entitled "Competency Standards and Teacher Certification", quoted by E. Mulyasa explained that to become a professional teacher, a teacher is required to have at least five things as follows: First, have a commitment to students and their learning process. Second, mastering in depth the subject matter being taught and how to teach it to students. The third is responsible for monitoring student learning outcomes through various means of evaluation. The four are able to 
think systematically about what they are doing and learn from their experiences (Mulyasa, 2004).

Should be part of the learning community in their professional environment. To get qualified / professional teachers to achieve educational goals, especially in schools, Cannot be separated from the spearhead of the educational institution, namely the head of madrasah in providing guidance to teachers as a component of teaching staff to produce quality output (Uno, 2010).

The formation of the teaching profession is carried out through pre-service and inservice education programs as revealed by James. "A teacher is person with targeting the responbility of helping others to learn and to behave in new differen ways." What is meant by the sentence above is "How a teacher must be responsible and accountable for what has become the duty of a teacher, because the future of the nation and state depends on the extent to which the institution it owns gives accountability to its graduates to society," (James M. Cooper: 2002).

Madrasah Ibtidaiyah Sanggulan which is the place of research, until now the number of students is 160 children. The number of educators is 12 people. The number of male educators is 2 people. And the number of female educators is 10 people. Given the unique nature of this school, namely the dominance of the number of educators by women.

Although the age of madrasas is still relatively old with all the limitations that exist. So there are so many things that must be initiated, fixed and developed by the head of the madrasah as the head of the madrasah just like any other school that has advanced. In addition, the public interest in the existence of these madrasas is a challenge for the head of madrasah in particular and the educators in these institutions, (Gulo, 2002).

Departing from the conditions above, the authors are interested in examining the extent of the potential of female teachers in improving the existence of MI Ma'arif Tabanan. Therefore the authors are interested in conducting a research entitled "The potential of female teachers in improving the existence of MI Ma'arif Tabanan Bali for the 2020 academic year."

Gender equality in Islam has actually been fought for by scholars to realize Islamic teachings based on the spirit of the Al-Qur'an and Hadith. The struggle for gender equality in the field of Islamic education has also been carried out since the time of the Prophet Muhammad to the modern era. Even so, objectively in its historical context, the movement of feminism or women's emancipation has become a widespread trend and has not only developed in the West but is also prevalent among Muslim activists who are concerned with the gender movement, which demands equal rights between men and women in all fields.

In the historical context, it seems that gender awareness was triggered by pejorative treatment found in various regions, especially in Europe and Asia in the pre-Islamic period. Discriminatory practices against women began to shed some light after the recognition and equality between men and women which was introduced by Islam in the revealed texts in the al-Qur'an and Hadith.

So it is not surprising that the rise of women who insist on equality of rights between men and women has actually been fought for by Muslims for a long period of time, and this can be seen from the birth of a number of female scholars recorded in the history of Islamic civilization (Goldschmidt, Boum, Goldschmidt, \& Boum, 2018). 
The research focus based on the background of the problems above are: 1 . What is the potential of female teachers in improving the existence of MI Ma'arif Tabanan Bali for the 2020 academic year? 2. What are the constraints and solutions for the coaching program for female teachers at MI Ma'arif Tabanan? To get answers to the focus of the problem in the study, the researchers conducted a study using a qualitative descriptive methodas described in the research methods section of this article.

The research objectives to be achieved in this study are: 1. To find out how the potential of female teachers in improving the existence of MI Ma'arif Tabanan for the 2020 Academic Year. 2. To find out what obstacles and solutions are faced by madrasah leaders in managing the potential of female teachers in improving the existence of MI Ma'arif Tabanan Bali for the 2020 Academic Year.

\section{METHOD}

This research approach uses a qualitative descriptive approach. It is a data analysis method that determines, interprets, and classifies data or information about the potential of female teachers in improving the existence of madrasah ibtidaiyah ma'arif sanggulan tabanan. The type of research that the author uses is "field research, which is a study that aims to conduct an in-depth study of a social unit in such a way as to produce well-organized and complete pictures of the social unit."

Determination of informants in research that uses qualitative research methods, informants are people who are the source of information in extracting data both as individuals and groups. So the informant is a figure who knows and has the data the researcher absolutely needs to be the main reference. To obtain the information or data we need for research, the author needs a valid or reliable source of information in order to obtain information about the situation and conditions in which the research was carried out, as well as to support the validity of the research that the author is working on. In this case the informants or data sources of this study were the head of madrasah, management of ma'arif educational institutions, teachers, employees, school committees, and parents / guardians of students.

Types, sources, and data collection techniques.the first type of data. The data in qualitative research are not numbers, but narrative descriptions, if there are numbers, these numbers are in the relationship of a description. In qualitative data processing there is no summation of data, thus leading to generalization.

The second source of data. What is meant by data sources in research is the subject from which data can be obtained. In this study the authors used primary data and secondary data as explained below. First, primary data (data from the first source), is data that is directly collected by researchers from participant sources, namely the head of madrasah and related elements, namely the ma'arif educational institution management, teachers, employees, school committees, and parents / guardians of students. Second, secondary data or data collected by researchers from literature as support for the first data. This data is in the form of school documents, or references related to research, about the results of observations, and make it easier for research to retrieve the data obtained when needed. Second, the data exposure (data display). According to nasution, who was quoted by kaelan, "making this display is also part of the analysis activity. By making data displays, the map can control the meaning of data which consists of various contexts ". The data that has been systematically 
compiled on data reduction are then grouped based on the main problem so that researchers can draw conclusions on the potential of female teachers in improving the existence of mi ma'arif sanggulan tabanan for the 2020 academic year. The three draw conclusions and verification (conclusions drawing and verifying). The next stage is drawing conclusions and verification. At this stage the researcher tries to draw conclusions based on the theme to find the meaning of the data collected. Drawing conclusions is the result of research that answers the research focus based on the results of data analysis. Conclusions are presented in a descriptive form of the research object guided by research studies.

After verification, it can be concluded that based on the results of the research presented in narrative form. Drawing conclusions is the final stage of data analysis activities. This conclusion is the final stage of the whole series of data processing. (Miles \& Huberman, 2012).

\section{RESULT AND DISCUSSION}

\section{Result}

Based on the results of research observations and data collection available. The author tries to discuss the focus of the problem that has been approved by the campus in submitting the thesis as follows: The potential of female teachers in improving the existence of MI Ma'arif Sanggulan Tabanan for the 2020 academic year. A madrasa educational institution is one indicator of its success incarrying out the educational process is inseparable from the ability of the leader or head of the Madrasah in managing and carrying out learning activities at the institution.

Likewise, the ability or potential of educators is very influential on the sustainability of an educational institution. In this case, we cannot deny the existence and potential of female teachers who have served at MI Ma'arif Sanggulan Tabanan.

The ability or potential of female teachers at MI Ma'arif is extraordinary. So that it is very helpful in improving the existence or existence of madrasas.

This is reinforced by the results of interviews with several MI Ma'arif Tabanan teachers about the potential of female teachers: As the result of an interview with Eka Timaya Laily Rahmah, S.Pd. The ability or potential of MI Ma'arif ustadzah in participating in raising educational institutions or carrying out madrasah missions is more of a motherly nature, so that students feel like their own children who should be able to get better services.

This is very much in accordance with the meaning of woman mentioned by the current scientific article writing. Com which states: "women are gentle and affectionate creatures because of their subtle feelings."meanwhile, the information given by mrs. Putriretnowosari, s.pd.i, a teacher of akidah akhlak.

In carrying out their duties as educators, female teachers are mainly because they are just vocation. So the matter of honorarium is the number two consideration. Eka Timaya Laily Rahmah Class VI Teacher.

Likewise, the information given by Mrs. Siti Aisyah, a member of the MI Ma'arif committee. I feel that female teachers find it easier to coordinate everything that is 
related to school activities. So that every thing or problem that involves coordination with the committee is resolved more quickly.

This is the case among the potential ustadzah of mi ma'arif in carrying out their duties as an educator. This is in accordance with the term limits that the writer sets about the potential meaning of the term limits according to the KBBI (Santoso, 2000). Potential is defined as an ability that has various possibilities or hopes for further development, whether it is in the form of strength, power, or ability that is obtained by the community directly or through a long process.

Besides having the potential or ability to carry out their duties as educators. Of course, female teachers cannot be separated from their shortcomings or limitations in carrying out their functions and duties as teachers. The following are the results of interviews that can be collected by the author regarding the shortcomings or limitations of female teachers in MI ma'arif.

Description of the Principal of MI Ma'arif Mrs. AtifatulKhamro, S.Pd. The obstacle that ustadzah often encounter in madrasah management is the ability to move quickly in all issues that involve extra-strenuous activities. As an example of activities carried out outside the madrasah that require physical endurance abilities. Because by nature women are feminine. Siti Aisyah. MI Ma'arif Committee, personal interview. Tabanan 26 August 2019.Ministry of Education.KBBI.op.cit.h. 1096.Atifatul Khamro. Head of Madrasah MI Ma'arif, personal interview. Tabanan 26 August 2019.

Based on the results of the above interview, the researcher can conclude that the potential of female teachers in madrasah ibtidaiyah ma'arif in carrying out their functions and duties as a teacher is based on compassionate nature as motherhood and sincerity, this is very in accordance with the arabic proverb which says "mother is the first school place." as well as a high sense of care in carrying out their duties as a teacher to provide the best service.

\section{Discussion}

From the results of extracting data on informants about the license of MI Ma'arif as follows: Based on information from Mikratul Aini, S.Pd, a grade IV teacher. One of the ways / efforts made by teachers to maintain and maintain the existence of MI Ma'arif is to maintain the quality of student achievement.

Based on information from Mikratul Aini, S. Pd, a grade IV teacher.One of the ways / efforts made by teachers to maintain and maintain the existence of MI Ma'arif is to maintain the quality of student achievement. According to a statement from Indah's mother Purnamadewi, S.Pd, a grade V teacher.

I felt comfortable teaching at MI Ma'arif. Because fellow teachers are always united and support each other. So that the family atmosphere is very thick. And relations with the surrounding community in particular are also well maintained. This information was also corroborated by Mrs. Eka Timaya Laily Rahmah, S.Pd. and other teachers. What makes me and my friends feel at home and keep the spirit of teaching at MI Ma'arif Tabanan is a callinghttps://ejurnal.iainlhokseumawe.ac.idAtifatulKhamro. Lok Cit.MikratulAini. Class IV teacher, personal interview.Tabanan 26 August 2019 Indah Purnamadewi.Class V teacher, personal interview.Tabanan 27 August 2019.

Soul to participate in educating and educating students properly. And it is also supported by a pleasant school atmosphere, intimacy between teachers who share both 
in joy and sorrow so that the family atmosphere feels very comfortable. Meanwhile, according to Mrs. Yayuk Sri Lestari as Chairman of the MI Ma'arif Committee.

The committee, as an extension of the educational institution, should disseminate any plans for learning activities or madrasah programs. So that what the goals and mission of the school can be achieved. Thus, public trust remains and is getting bigger.

Based on the results of the interview, a common thread can be drawn that all parties, both teachers and the committee, work together to advance MI Ma'arif Sanggulan Tabanan because of the support of a comfortable school environment. This is in accordance with the limitations of the term Existence which is taken from the Big Indonesian Dictionary.

Constraints and solutions for the female teacher development program at the MI Ma'arif Tabanan. In running and implementing the madrasah program, of course, it does not always go as expected. In implementing school programs in terms of coaching female teachers, it is also not free from obstacles.

The obstacles encountered in coaching female teachers at MI Ma'arif include the following interviews:According to the explanation by the head of Madrasah, Mrs. Atifatul Khamro, S.Pd.

As the Head of Madrasah, I sometimes encounter obstacles in implementing female teacher development programs in terms of improving the quality of human resources. One of the biggest obstacles is finance or coaching costs Eka Timaya Laily Rahmah. Op Cit.Yayuk Sri Lestari. Madrasah Committee, personal interview. Tabanan 26 August 2019. Indonesia Dictionary.Op.Cit. p. 357 internal teachers. Meanwhile, if you wait for the guidance program from the government in my opinion it is too long. Meanwhile, according to the explanation from Mrs. Dessy Puspitasari, S.Pd. class III teacher.Constraints from coaching are related to improving the quality of human resources in addition to funding constraints sometimes clashing with the condition of teachers who have babies so that they cannot be left behind.

According to Mr. H. Drs. Subagio as Chairman of the Ma'arif Education Institute. In terms of coaching female teachers at MI Ma'arif in 2020, there are still obstacles in terms of improving the quality of human resources. Because Madrasah Institutions are still focused on filling new rooms in order to fill classrooms for new students, which continues to grow every year. However, even though the development of human resources has not been fulfilled, the teacher councils have fulfilled the Competence of Teachers, because the teachers have fresh knowledge because many have just graduated from teacher education because they serve while studying (Farrell, 2015).

After listening to the results of several interviews regarding the constraints of ustadzah guidance at MI Ma'arif Sanggulan Tabanan, it can be concluded that the fundamental obstacle is the lack of funds to carry out coaching in an effort to improve human resources because it is still focused on providing classrooms for new students who need 2 rooms class (Mulyasa, 2005). However, the head of madrasah is still looking for a solution so that the teacher council can continue to strive to improve the ability of the teaching profession, as stated by M. Saifulloh that in improving the quality of educators they must look at the conditions of the school environment, if it is not possible to implement the program then it should not be forced (Saifulloh, Muhibbin, \& Hermanto, 2012). Dessy Puspitasari as a classroom teacher said that in fostering ustadzah in improving the quality of teacher human resources, madrasah in this case 
the madrasah principal must go a step further by monitoring and supervising the teacher board which functions as a supervisor so that there is no decline in the quality of education of the institutions they manage. All teacher councils are urged to always pay close attention to the situation and information on the development of the world of education in other schools via the internet which is already available at schools and through the private internet.

\section{CONCLUSION}

Based on the results of observations, data collection and documentation as well as the results of data analysis, it can be concluded that the potential of ustadzah in improving the existence of MI Ma'arif Sanggulan Tabanan in the 2020 academic year in carrying out its duties, and its function is more based on their character as women, namely more compassionate, sincere and devoted., and care about the world of education. So that this characteristic is what the researchers observed as a special attraction as a factor that parents are more interested in sending their children to MI Ma'arif Sanggulan Tabanan.

Meanwhile, the obstacles and solutions for the ustadzah guidance program at MI Ma'arif Sanggulan Tabanan. The problem with teacher coaching programs is the lack of school funds that are still focused on building classrooms. Solutions that can be given are to establish school businesses such as school canteens, school cooperatives, and rent out canteens. With this research, hopefully it can provide insight and knowledge in improving the world of education in Indonesia

\section{REFERENCES}

[1] Departemen Agamag RI. (2020). Al Quran dan terjemahan. Al-Qur'an Terjemahan.

[2] Farrell, P. (2015). Life outside academia: on becoming an expert teacherresearcher. International Journal for Transformative Research. https://doi.org/10.1515/ijtr-2015-0003

[3] Goldschmidt, A., Boum, A., Goldschmidt, A., \& Boum, A. (2018). Islamic Civilization. In A Concise History of the Middle East. https://doi.org/10.4324/9780429495526-7

[4] Gulo, W. (2002). Metodologi Penelitian. Gramedia Widiasarana Indonesia.

[5] Miles, M. B., \& Huberman, M. A. (2012). Analisis Data Kualitatif: Buku Sumber Tentang Metode-Metode Baru. Universitas Indonesia_UI Press.

[6] Mulyasa, E. (2004). Becoming the Principal of a Professional School in the Context of making MBS and KBK a success. Bandung: Remaja Rosdakarya.

[7] Mulyasa, E. (2005). Being a professional teacher, creating creative and fun learning. Bandung: Rosda Karya.

[8] Saifulloh, M., Muhibbin, Z., \& Hermanto, H. (2012). STRATEGI PENINGKATAN MUTU PENDIDIKAN DI SEKOLAH. Jurnal Sosial Humaniora. https://doi.org/10.12962/j24433527.v5i2.619

[9] Santoso, A. (2000). Kamus Lengka Bahasa Indonesia. Kamus Lengka Bahasa 
Indonesia.

[10] Undang-Undang Republik Indonesia. (2003). Nomor 20 Tahun 2003. Tentang Sistem Pendidikan Nasional.

[11] Uno, H. H. B. (2010). Model pembelajaran: menciptakan proses belajar mengajar yang kreatif dan efektif. Jakarta: Bumi Aksara.

[12] Wigati, Y., \& Riyadi, A. (2019). Interpersonal Communication Model in the Book "Aisyah" by Sulaiman An-Nadawi. Ilmu Dakwah: Academic Journal for Homiletic Studies. https://doi.org/10.15575/idajhs.v13i2.6204 